Gofman, J. W., Jones, H. B., Lyon, T. P., Lindgren, F. T., Strisower, B., Colman, D. \& Herring, V. (1952). Circulation, 5, 119.

Herrick, J. B. (1912). F. Amer. med. Ass. 59, 2015.

Katz, L. N. (1952). Circulation, 5, ror.

Mackenzie, J. (I908). Diseases of the Heart. London: Oxford Medical Publications.

\title{
Glinical Aspects of Nutritional Problems in Obliterative Vascular Disease
}

By A. M. BoyD, Department of Surgery, University of Manchester

Text not received for publication.

\section{Physiological Aspects of Nutritional Problems in Obliterative Vascular Disease}

By A. H. RaTCLIFFe, Department of Surgery, University of Manchester Text not received for publication. 